Valerie Lang Waldin

\title{
Introduction to animal law
}

Resources for online research and study

A nimal law is the body of statutory and case law governing the treatment of nonhuman animals, including wildlife, companion animals, and animals used for research, entertainment, and food. Emerging rapidly on academic and legal horizons since 2000, entire programs of study at all levels are now dedicated to training students to be effective humane educators, attorneys, law enforcement officers, and citizens.

High-profile court cases, such as SeaWorld v. California Coastal Commission, along with the proliferation of animal protection documentaries, such as Blackfish, Earthlings, and Tyke: Elephant Outlaw, have raised profound questions about our treatment of other species. Animal protection is now a mainstream phenomenon, largely due to the Internet and social media providing instant visibility to and awareness of the critical issues of our time.

To effect progress, we must navigate the legal system. This compilation of key animal law repositories, sources of federal and state statutes, case law, open access animal law journals, programs of study, and LibGuides serves as a basic set of tools for locating and understanding the exciting and enduring discipline of animal law.

\section{General}

- Animal Legal Defense Fund (ALDF). Founded in 1979 by attorneys dedicated to stronger enforcement of animal protection laws, ALDF's mission is to advance the protection of animals via the legal system. Recognized for its high profile lawsuits nationally and statewide, ALDF is consistently instrumental in advancing stronger animal cruelty laws, serving as a resource for law students and animal law attorneys, and challenging case law and legislation that is detrimental to animals. Access: https://aldf.org/article/animal-law-101/.

\section{Animal law repositories}

- Animal Law Commons. With more than 900 full-text scholarly articles, book chapters, dissertations, working papers, conference proceedings, and other original scholarly works on worldwide animal law issues, the Animal Law Commons is made available via the Digital Commons Network. Access: http:// network.bepress.com/law/animal-law/?utm _campaign=PDFCoverPages\&utm_medium =PDF\&utm_source=engagedscholarship.csuohio. edu\%2Fresearchguides\%2F16.

- Animal Law Resource Center. A program of the National Anti-Vivisection Society, this site provides access to legislation and cases pertaining to the rights and welfare of animals. Links are provided to both pending legislation and existing laws, as well as model animal laws, bibliographies, and case law digests. Access: http://www.animallaw.com/.

- Michigan State University Animal Legal and Historical Center. First opened in 2002, the center includes a compilation of 1,200 full-text U.S., historical, and U.K. cases; more than 1,400 U.S. statutes; more than 60 topics; legal articles on a variety of animal issues; and an international collection. Provided are current case law and legislative initiatives, topical introductions, animal law

Valerie Lang Waldin is associate professor/reference librarian, email: v.waldin@hvcc.edu, at Hudson Valley Community College's Dwight Marvin Library

(c) 2020 Valerie Lang Waldin. This work is licensed under a Creative Commons Attribution 4.0 International (CC BY 4.0) License (https:// creativecommons.org/licenses/by/4.0/). 
conferences and events, new books in animal law, and frequently asked questions. Access: https:// www.animallaw.info/.

\section{Federal statutes}

- Congressional Research Service Brief Summaries of Federal Animal Protection

Statutes. Listed alphabetically by statute, this report contains brief summaries of federal animal protection statutes, along with statutes enacted to implement certain treaties. In addition to animal protection legislation, these summaries also consist of statutes that involve animals but that are not necessarily animal protection statutes (last updated in 2010) Access: http://nationalaglawcenter. org/wp-content/uploads/assets/crs/94-731.pdf.

- Hudson Valley Community College Animal Law, Advocacy and Policy: Federal Laws. This resource provides a comprehensive listing of, and links to, key U.S. federal animal laws, codification, and description and dates amended, including the following statutes: Animal Crush Videos; Animal Fighting Venture Prohibition; Animal Health and Disease Research; Animal Welfare Act; Endangered Species Act; Fishery Conservation and Management Act; Horse Protection Act; Humane Slaughter Act; Lacey Act; Marine Mammal Protection Act; Marine Protection, Research, and Sanctuaries Act of 1972; Migratory Bird Treaty Act; Twenty-Eight Hour Law; and the Wild Free-Roaming Horses and Burros Act. Access: https://libguides.hvcc. edu/animalstudies/fedlaws.

- United States Department of Agriculture National Agricultural Library, Animal Welfare Information Center. The Laws and Guidelines section of this site provides information on federal laws and regulations that govern animals used in research, testing, teaching, and exhibition. Specific laws are the Animal Welfare Act, the Horse Protection Act, the Humane Slaughter Act, and the Twenty-Eight Hour Law, along with legislative histories, amendments, Government Accountability Reports, and testimonies, as well as compliance assistance. This site also features animal welfare guidelines, policies, and codes of practices from around the world. Access: https://www.nal.usda.gov /awic/federal.

\section{State animal cruelty statutes}

- American Society for the Prevention of Cruelty to Animals (ASPCA). ASPCA was the first animal protection organization in the United States, originating in 1867. Among the many offerings of this site is a listing of farmed animal confinement bans by state. Access: https:// www.aspca.org/animal-protection/public-policy /farm-animal-confinement-bans.

- Animal Law Resource Center. A program of the National Anti-Vivisection Society, the Animal Law Resource Center contains model state laws, bibliographies, legislation, and legal matters pertaining to animals and the law, animal cruelty, animal control, laboratory animal welfare, and wildlife management. Searchable by individual state. Access: http://www.animallaw.com/.

- Animal Welfare Institute Farmed Animal Anti-Confinement Legislation. This site lists state legislation prohibiting intensive confinement crates for calves raised for veal and gestating sows, and battery cages for egg-laying hens. Access: https://awionline.org/content/farm-animal -anti-confinement-legislation.

- Michigan State University Animal Legal and Historical Center. The Animal Legal and Historical Center contains an interactive map with links to the animal anti-cruelty laws for all 50 states. Comparative tables include dangerous dog laws, pet purchaser protection acts, laws concerning dog tethering, pet breeding, strict liability legislation on dog bites, and leash laws. Additional state animal law provisions include reporting animal cruelty and enforcement powers, animals in parked cars, animal sexual assault laws, and veterinary reporting and immunity laws. Access: https://www.animallaw.info/content/state-animal-anti-cruelty-laws and https://www.animallaw.info/site/comparative-tables.

- National Agriculture Law Center/University of Arkansas. The National Agricultural Law Center serves the U.S. agricultural community and is an affiliate of the USDA National Agricultural Library. The site features an interactive map linking to the states' animal cruelty statutory texts, as well as dates of possible expiration. Access: https://nationalaglawcenter.org/state-compilations/ animal-cruelty/.

- New York State Humane Association (NYSHA). NYSHA's ongoing activities and training 
programs focus on animal cruelty law, legislation, and humane education. The NYSHA website includes a renowned, freely available manual "Investigating Animal Cruelty in NYS," complete with the full text of New York's animal cruelty statutes and legal resources for law enforcement, veterinarians, and humane agencies in animal cruelty cases. The animal cruelty investigative principles found on this website are applicable across states. Access: https://www.nyshumane.org/.

\section{State animal law rankings}

- Animal Legal Defense Fund (ALDF).

ALDF annually compares the overall strength and comprehensiveness of laws with regard to the definition of an animal, veterinary reporting of animal cruelty, breed-specific legislation, sexual assault of animals, courtroom animal advocate programs, civil nuisance abatement, laws against dogs in hot vehicles, court-ordered psychological evaluations, and post-conviction possession bans. Access: https://aldf.org/project/2018 -us-state-rankings/.

- Humane Society of the United States. Evaluated annually, state law rankings are based on strength of legislation in the following areas: animal fighting, animal cruelty, wildlife protection, dangerous wild animals as pets, companion animals, animals in research, farmed animal protection, fur and trapping, puppy mills, and equine protection. Access: https://blog. humanesociety.org/wp-content/uploads /2018/12/Total-Scores-2018-FINAL-1.pdf, https://blog.humanesociety.org/wp-content /uploads/2018/12/State-Rank-2018-AL-MO-1. pdf, and https://blog.humanesociety.org /wp-content/uploads/2018/12/State-Rank -2018-MT-WY-1.pdf.

\section{Case law}

- Animal Law Resource Center. The Animal Law Resource Center features case briefs arranged alphabetically by state and searchable by category, case name, or keyword. Access: http://www.animallaw.com /Case-Law.cfm.
- Animal Legal and Historical Center.

The center documents animal law cases nationwide from 2010 to the present, including case citations, plaintiffs/defendants, case summaries, and judicial opinions in full text. Organized by year with advanced search options. Access: https://www.animallaw.info /site/prior-animal-law-cases-month.

- Animal Legal Defense Fund (ALDF). ALDF archives animal law case summaries throughout the country. Search filters include focus area, date, and case status. Cases are distinguishable in nature by the following categories: advocacy, collaborative efforts, criminal justice, legal education, legislative initiatives, litigation, and regulation. Access: https://aldf.org/cases/.

\section{Open access animal law journals}

- Animal Law Review. Dating back to 1994, the Animal Law Review is the nation's oldest law journal devoted entirely to the discussion of legal issues relating to animals, with national recognition and several hundred subscribers. Full text of past volumes available from 1994 to 2015, with synopses of current volumes Access: https://law.lclark.edu/law_reviews /animal_law_review/.

- The Animals' Advocate. This is the quarterly newsletter of the Animal Legal Defense Fund, which includes federal and state action alerts, contemporary issues, and nationwide litigation. Full-text access is available from 2000 to the present. Access: https://aldf.org/article /animals-advocate/.

- Global Journal of Animal Law. The Global Journal of Animal Law is an openaccess legal journal addressing the legal status of animals. Submissions are accepted on a rolling basis. Full-text access from 2013 to the present. Access: https://ojs.abo.fi/ojs /index.php/gjal/about.

- Journal for Critical Animal Studies. The Journal for Critical Animal Studies, a project of the Institute for Critical Animal Studies, originated in 2003. A free open access, peer-reviewed electronic journal, it encourages submissions omitted from mainstream journals, including the use of photographic, video, and new media work, and allows contributions from 
activists. Full-text access is available from 2013 to the present. Access: http://journalforcriticalanimalstudies.org/issues/.

\section{- Journal of Animal and Natural Re-} source Law. A peer-reviewed publication of the Michigan State University College of Law, this journal explores the legal and public policy issues surrounding animals at local, state, national, and international levels. Full text access is available from 2005 to the present. Access: http://www. msujanrl.org/.

\section{Programs of study}

- Animal Law Courses offered in United States, Canada, Australia, and New Zealand. In 2000, there were 12 student chapters and nine law schools offering courses in animal law. In 2019, more than 165 law schools in the United States and Canada offer or have offered a course in animal law, with 11 in Australia and New Zealand. The Animal Legal Defense Fund provides a compilation of these offerings. Access: https://aldf.org/article/animal -law-courses/.

- Animals and Society Institute (ASI). Founded in 1983, ASI cosponsors fellowship programs for Human-Animal Studies scholars and assists universities outside of the United States with the creation of animal welfare programs. A listing of more than 350 course and degree programs in law schools and college courses taught around the world is available by region and state, by country or region, including Europe, Asia, Canada, Latin America, and Oceania. Access: https:// www.animalsandsociety.org/human-animal -studies/courses/.

\section{Animal Law LibGuides}

- Harvard Law School Animal Law Research Guide. Intended as a starting point for animal law research and not an all-inclusive resource, this guide includes treatises and introductory texts, organizations, research guides, treaties and international agreements, federal statutes, state legislation, case law, blogs, news, and journals. Access: https://guides.library.harvard.edu/animallaw.

- Hudson Valley Community College Dwight Marvin Library Animal Law, Advo- cacy and Policy Research Guide. This extensive guide provides legal, advocacy, and policy information surrounding animal abuse and interpersonal violence, animal control, animal fighting and breed specific legislation, animal intelligence, animals in entertainment, animals used for clothing, research and food (factory farming), cats, companion animals, dangerous dogs, documentaries, a comprehensive listing and description of federal animal laws, GATT and NAFTA, globalization, horse breeding, racing and slaughter, humane education, investigating animal cruelty, lobbying and legislation, New York State Bar Association Committee on Animals and the Law, the Nonhuman Rights Project, negligence, puppy mills, state law rankings, wildlife, wills and trusts, works by philosophers Peter Singer and Tom Regan, and the Animal Rights and Welfare Historical Collection. Access: https://libguides.hvcc.edu /animalstudies/.

- Pace Law School Library Animal Rights Law Research Guide. Provides an up-to-date "Animal Law Blawg" about current issues on animal protection of all species, a specific focus on factory farming as well as legal standing, international and foreign animal law, statutes and case law, journals, databases, books, and select Internet sources on animal rights in the legal system. Access: http://libraryguides.law. pace.edu/animals.

- UCLA School of Law Hugh and Hazel Darling Animal Law Research Guide. The Animal Law Program at the UCLA School of Law is supported by a substantial endowment from the late television personality Bob Barker, ensuring that animal law courses will be offered at UCLA each year. UCLA's Animal Law Research Guide includes introductory materials and suggested readings on the property status of animals, the animal rights versus welfare debate, standing and access to the courts, factory farmed animals, animal cruelty and the First Amendment, animals and philosophy, animals in domestic disputes, animals and women's studies, and the study and practice of animal law. Also available are cases, statutes, regulations, journals and news, books, blogs, student and attorney groups, and online research. Access: http://libguides.law.ucla.edu/c. php?g=183369\&p=1208726. n 